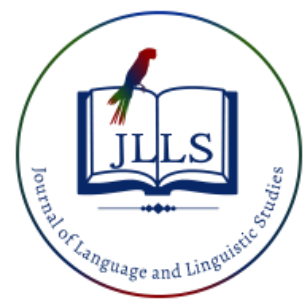

Available online at www.jlls.org

JOURNAL OF LANGUAGE

AND LINGUISTIC STUDIES

ISSN: $1305-578 \mathrm{X}$

Journal of Language and Linguistic Studies, 17(4), 1920-1931; 2021

\title{
Translatability of English and Arabic Hypothetical/Unrealizable Propositions
}

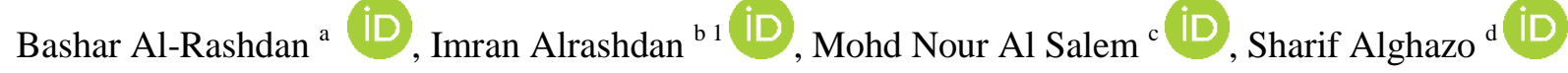

${ }^{a}$ Mu'tah University, Jordan

${ }^{b, c, d}$ University of Jordan, Jordan

\section{APA Citation:}

Al-Rashdan, B., Alrashdan, I., Al Salem, M.N., \& Alghazo, S. (2021). Translatability of English and Arabic Hypothetical/Unrealizable Propositions. Journal of Language and Linguistic Studies, 17(4), 1920-1931. Doi: 10.52462/jlls. 139

Submission Date:28/05/2021

Acceptance Date:31/07/2021

\begin{abstract}
Although translation is a means of intercultural communication, it represents a challenge when it comes to rendering the intended meaning of some propositions, particularly because every language has its distinctive features and structures that may not be accurately rendered into the target language. This challenge is reinforced when translation occurs between two languages that belong to different origins such as English and Arabic. This paper explores the translatability of a grammatical construction (viz. Hypothetical or unrealizable proposition) from English to Arabic, and vice versa. The paper shows - through examples from both languages-that regardless of how carefully translation is conducted, incomplete meanings are usually rendered into the other language. It, moreover, asserts the interlanguage translatability of such propositions and notions. In principle, but by no means exclusively, Arabic is treated as a source language and English as a target language for the purpose of translation. But in many places, this order is reversed. The analysis has implications for translation-related courses, particularly in crucial areas such as legal translation where accurate meanings are carefully searched for.
\end{abstract}

Keywords: Grammar; Hypothetical propositions; Translatability; English; Arabic

\section{Introduction}

English and Arabic belong to two different language families. Hence, they manifest some different constructions that may pose a challenge to translators to render the appropriate meaning(s) in the target language. This situation has led some to argue for the untranslatability of such different structures. Although hypothetical propositions exist in both English and Arabic, the translatability of these propositions is questioned due to differences in the syntactic structures used to show these meanings. Hypothetical propositions are associated with syntactic constructions which express states, processes, and locutions touching on modal means of indicating speakers' attitudes and/or psychological positions in communicative behaviour. This implies that a consideration of the tense, mood and modality used to express hypothetical propositions in the two languages is necessary to understand how the most appropriate rendition of meaning can be reached. This study presents examples of

\footnotetext{
${ }^{1}$ Corresponding author.

E-mail address: i.alrashdan@ju.edu.jo
} 
hypothetical propositions from Modern Standard Arabic (MSA) and counterparts from English and accounts for the translatability of these constructions in the two languages.

\section{Tense, Modality and Mood in English and Arabic}

Tense is a Latin word that means time; it is a grammaticalized syntactic category that expresses temporal information about actions, events or states (Ouali, 2018). However, tense is different from time: While tense is a syntactic category, time is a notion. This relates to the form-function relationship in linguistics. In some cases, the past tense can be indicative of future time. In addition, tense is an essential component of the sentence. Burton-Roberts (2016) believes that there should be a finite verb (i.e., tensed verb) in every sentence. English is similar to Arabic in that each has two tenses: past and non-past or present. However, they differ in the formal realizations of these tenses. While English has 16 different tense forms, Arabic has only two (Gadallah, 2017). Another difference is that Arabic verbs focus on the state of the action rather than the time as is the case in English verbs and that reference to time in Arabic is contextual; that is, it can be implicated in the context (see Sterling, 1904). As for the future, it is not a tense; rather it is recognized as a modality. Both languages express future time in a number of parameters. In English, for example, the auxiliary verb will is used to express future time while, in Arabic, either the modal auxiliary sawfa or the clitic sa precedes the present or imperfective form to express future time (Alhawary, 2016).

Modality is a cross-linguistic semantic category of the clause that is generally defined as "the linguistic phenomenon whereby grammar allows one to say things about, or on the basis of, situations which need not be real" (Portner, 2009, p. 1). The question that is raised is: What are the linguistic features that allow one to express modality? In answering this question, Portner (2009) categorises modal forms into three types: sentential, sub-sentential, and discourse. Sentential modality includes both modal auxiliaries and adverbials expressing modality at the level of the sentence. Sub-sentential modality comprises expressions of modality at the level of constituents, that is, constructions and phrases within the clause. Discourse modality refers to any expression of modality at the level of discourse rather than semantics; discourse modality, as Portner $(2009$, p. 3$)$ puts it, "is any modal meaning which is not part of sentential truth conditions." In Arabic, modality is expressed by means of a class of words called Alnawaasikh (cancellers) - further divided into sub-classes called akhawaat 'sisters.' These words are further classified into six types of modality: epistemic, alethic, deontic, evaluative, boulomaic, and temporal (Anghelescu, 1999). In English, however, modality is expressed using core and peripheral constructions. These result in two main types of modality in English, viz. root and epistemic and these are further subdivided. Root modality is divided into physical and deontic, and epistemic modality into problematic and implicative (Larreya, 2009).

Mood is highly related to modality, but, unlike modality, mood is a grammatical, rather than semantic, category, which is not universal. Mood basically refers to a set of "syntactic and morphological forms showing speaker-attitude to the utterance" (Fenn \& Schwab, 2018, p. 60). In many languages that have a mood system — particularly European languages - mood is a morphosyntactic category which is realised in terms of a distinction between indicative and subjunctive (see Palmer, 2001). In English, for example, there are three moods: indicative (e.g., I have seen it already), subjunctive (e.g., learning another language, be it second or third, is challenging), and imperative (e.g., close the door). In Arabic, mood is "indicated by suffixes or modifications of suffixes attached to the present tense verb stem, and the phonological nature of the verb stem determines what form the suffix will take" (Ryding, 2005, p. 53). Unlike English, mood marking in Arabic only appears on the present verb; consequently, it is non-finite. There are four moods in Arabic: indicative, subjunctive, imperative, and jussive (e.g., lam naktub 3anhu fi assuhuf "we did not write about him in 
newspapers'). The latter, which is not found in English, is used in Arabic to show "an attitude of command, request, or need-for-action on the part of the speaker" (Ryding, 2005, p. 444).

Based on the foregoing, we notice that English and Arabic manifest different tense forms, modality and mood marking. Therefore, in translation, these differences pose great difficulties on the part of translators to render structures and propositions from one language to another. What follows is a review of some studies on the translatability of propositions from English to Arabic, or vice versa.

\section{Literature Review}

The literature on English-Arabic translation largely abounds with studies that show the difficulties associated with rendering the appropriate meaning from the source language to the target language. Eades (2011), for example, discussed the difficulties associated with translating modals from English into Arabic. In an attempt to explore the needs of trainees in the field of translation, the researcher analysed their mistranslations and found that it is difficult to translate modals from English to Arabic due to the complex nature of the structure and meanings of modals. He also found that the respondents failed to render the intended meaning of modal verbs as they relied on the dictionary meaning of these verbs. This difficulty was found to result in some trainees overlooking translating modal verbs altogether. The researcher concluded that knowledge of the syntactic differences between the two languages is necessary for translators to produce more acceptable renditions in the target language.

Other studies have focused on the difficulties, and consequences of these difficulties, associated with translating modal verbs in more crucial registers. Mahdi and Husain (2012) conducted a study to explore the problems and difficulties associated with translating modal verbs from English into Arabic in legal texts. To this end, the researchers used textual analysis to collect and analyse data from some English legal texts and their translation into Arabic. The findings showed that since English modal verbs have manifold functions, translating them into Arabic must be done with careful thought of the meaning and context. The researchers found that modals in English legal texts can be effectively translated into Arabic if the knowledge of the functions and rules of the modal verbs in the two languages is developed to ascertain that the appropriate equivalent is used in these carefully-structured and constructed texts.

In a similar study, Al-Mahjoob (2016) studied the translatability of modals in English legal texts into Arabic by identifying the functions and meanings of modals in the two languages. Text analysis was used to collect and analyse data. In particular, the researcher analysed how the Convention against Torture and Other Cruel, Inhuman or Degrading Treatment or Punishment is translated into Arabic. The results revealed that the modal shall is the most frequently used modal in the English legal text which is the least frequently used in other registers - and that its meaning differs from one text to another. In legal registers, shall expresses obligation while in non-legal texts, it expresses futurity. It was also found that the modal shall does not have any lexical equivalent in Arabic and that the modal may when expressing permission is rendered as yajuuz and when expressing possibility as qad in Arabic.

Some studies were concerned with how Arabic modality is rendered in English and other languages. Moindjie (2015), for example, conducted a study to gauge the translatability of modals from Arabic into French and English. The researcher used textual analysis to identify the functions of modals in all three languages before exploring their translatability. Upon analysis, the researcher found that modals are more frequently used in English than in Arabic and that Arabic modals of probability are the most frequent unlike English where modals of obligation and willingness are as frequent. As for the translatability of modality, it was found that modals of obligation are often translated using 
literal translation and that modals of probability, willingness and usuality are translated using oblique translation such as modulation, transposition, and supplementation.

Research has also examined the extent to which modality is fully acquired, and also translatable, by Arabic speaking translators. Al-Qudah and Yasin (2016) explored the acquisition of modals by English, as a foreign language (EFL), learners at the University of Jordan and their ability to translate sentences containing English modals into Arabic. To this end, the researchers analysed the use of modals in the writings of 26 students majoring in applied English at the University of Jordan. The students were asked to identify the functions and meanings of English modals in some sentences and to translate them into Arabic. The findings showed that many respondents were not able to render the intended meaning of English modals into Arabic, a finding which was attributed to the lack of competence on the part of students on how modals function in the two languages.

\section{Methodology}

This paper mainly deals with so-called unrealized/unrealizable, non-factive (and perhaps contrafactive) communications in English and Arabic, with a view to indicating their inter-translational flexibility. To this end, the researchers collected a corpus of examples from both languages to test the (un)translatability of unrealizable constructions. The Arabic examples included some verses from the Holy Quran and from other sources. The analysis was validated by three experts in linguistics and translation who provided the researchers with suggestions and modifications.

\section{Analysis and Discussion}

This paper discusses whether, and to what extent, each of the two languages has the appropriate linguistic potential to handle the translation of the phrases and connotations in question. Mitchell and El-Hassan $(1994$, p. 8$)$ argue that "[u]ncertainty, doubt, unwillingness for whatever reason to subscribe to the fact of a given state of affairs entails consideration from a modal standpoint of various indicators of time, whether in relation to the present or the past." From a formal viewpoint, the structures aimed at in this study must of necessity include reference to tense, modality, and mood in both languages. Tense is seen here as a deictic grammatical category with two terms: past and non-past. In both languages, this distinction is valid (e.g., closed and closes and Pağlaqa and juğliqu). The former (i.e., closed Pağlaqa) generally - and rather tentatively — places the action expressed by the verb at a time preceding the moment of utterance, while the latter (i.e., closes juğliqu) locates the action at a time not preceding the moment of utterance. The syntagmatic co-occurrence of time adverbials with these forms of the verb usually supports this tentative claim. Consider the examples at (1) and (2).

1. He closed the gate (ten minutes ago).

Pağlaqa albawwaabata munðu Sašri daqaa?iq.

2. He closes the gate after ten minutes. juğliqu albawwaabata baßda ৎašri daqaa?iq.

But this is an oversimplified statement about tense; the relationship between tense and time in English and Arabic is much more complicated, as discussed above, and far from being in a one-to-one correspondence. It is especially in constructions and phrases that concern us in this article that the mismatch between tense and time is most obvious, as indicated in Example 3:

3. I wish I knew the answer.

In this hypothetical sentence, the speaker uses a past tense 'knew' in the embedded clause not in a past time sense but rather in reference to a non-past time (present or future), for instance:

4. I wish I knew the answer now. 
The sentence *I wish I knew the answer yesterday is ungrammatical. The Arabic translation of 3 must match this temporal association. It is, therefore, incorrect to translate it with a past time reference Saraftu, viz. 'laytanii Caraftu iljawaab'. The correct translation is laytanii Pa९rifu (non-past tense, nonpast time) iljawaab. English and Arabic do not match here, for (4) laytanii Saraftu (past tense, past time) iljawaab is more akin to 'I wish I had known the answer' which implies that the speaker did not know the answer when he uttered the sentence. More about 'wish' and its translation into Arabic appears later. Suffice it to note here that English does not allow a non-past tense in the embedded clause following the matrix clause 'I wish'.

Conditional sentences involving hypothetical states and circumstances also present similar translational issues. Consider Example 5:

\section{Farmers would be very happy if it rained.}

The past tense in the if-clause here does not signal past time at all; it rather places the act of raining in the non-past time (present or future). The phrase 'would be' in the matrix clause makes it very clear that the time indicated must be non-past. Therefore, adding a past time adverbial (e.g., yesterday/last week) to 5 renders it ungrammatical; hence, * Farmers would be very happy if it rained yesterday. The Arabic translation of 5 must reflect this syntacto-semantic association. Perhaps Arabic 6 is equivalent to English 5 above:

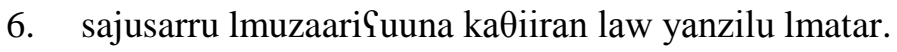

Of course, 5 and 6 imply that rainfall is unlikely. Note that 'I wish I knew the answer' and 'Farmers would be very happy if it rained' as well as the corresponding Arabic translations express unrealized (probably unrealizable) propositions involving tense and modality implications: the former being a wish, the latter an unreal condition unlikely to materialize under the given circumstances. The particle law in Arabic 6 above underlines this semantic implication. Neither the conditional Pin nor the conditional Piðaa is applicable in the translation of 5 and 6. The former particle (i.e., Pin) introduces a real (and, therefore, potentially realizable) situation. The latter (i.e., Piðaa), on the other hand, generally introduces propositions which are almost certain to happen. The Holy Quran abounds in conditionals introduced by Piðaa. Examples follow.

7.

a. Piðaa dzaa?a naSru LLaahi walfath 'when the victory of Allah and conquer come'.

b. Piðaa ssamaa?u nfaTarat 'when the heaven is cleft asunder'.

c. waPiðaa lkawaakibu ntaOarat 'and when the planets/ stars are dispersed'.

Exegetists - i.e., interpreters of the Holy Quran - have always been fully aware of the meaning of the conditional Piðaa in line with the traditional Arabic grammarians. They consider it an adverbial conditional of future time implying that the event associated therewith is imminent. For instance, Abdul-Ghani Daqar (1982, p. 6) glosses it as "Piðaa Đarfiyya- takuunu ğaaliban Đarfan lilmustaqbal". To render it faithfully into English, one has to use the adverbial 'when' as in the translation of the Holy Quran verses just cited. But it is not only in Quranic translation that Piðaa must be rendered as 'when' in English. Here are some common examples from spoken Arabic.

8.

a. Piðaa Talaৎat iššamsu tartafiৎu darajatu lharaarah. 'When the sun rises, temperatures rise.'

b. Paatiikum?iðaa ktamala lbadru 'I'll come to you when the moon is full.'

c. Piðaa ra?ajta Panjaabu llay $\theta$ i baarizatan fala taĐunnanna Panna llay $\theta$ a yabtasimu 'when you see the teeth of a lion bare, do not take it that the lion is smiling.'

In the following line of verse by Tarfa bin Al-Abd, a pre-Islamic Arab poet, a similar sense of ?iðaa is probably encoded. 
9. Piðaa lqawmu qaaluu man fatan xiltu Pannanii Guniitu falam Paksal walam Pataballadii 'when my people ask "who is champion” I reckon I am meant, and so I am neither inactive nor lethargic.'

Usually, a past tense follows the conditional Piðaa and its reference is invariably non-past time, as shown in the above examples. Having said that one must hasten to add that there are examples in spoken and Modern Standard Arabic where Piðaa expresses conditions which may or may not be realized. In such cases the translation of Piðaa is quite similar to that of Pin which is translatable as 'if' in English.

10. Piðaa šuft samiir sallimli Galeeh 'if you see Sameer, give him my regards.'

This is a kind of common expression in spoken Arabic and does signal a circumstance which is realizable or not (the addressee may or may not see Sameer). Similarly, Sentence (10) in Modern Standard Arabic expresses a condition which may or may not be fulfilled.

11. Piðaa nadzaht fil Pimtiћaan fasawfa Paštarii laka darraadzah 'if you pass the test, I will buy you a bike.'

On the other hand, this sentence can be translated as 'when you pass the test ...' assuming that the candidate may have to repeat the test. Thus, the circumstances of the conditional clause determine the appropriate meaning and consequently the correct translation. It must be added that when Piðaa is followed by a negative particle (maa or lam) in spoken Arabic, the appropriate translation is definitely 'if', as in 12 below:

12. Piðaa maa nadzahtiš, maa baštariilak darraadzih 'if you don't pass, I won’t buy you a bike.'

\subsection{Mood and Modality}

Mood and modality are grammatical and semantic categories that are also relevant to the task in hand. Mood, strictly speaking, concerns the various verb forms in language. But the term is also used in reference to sentence types and expressions in which these verb forms are manifested. Grammarians and linguists commonly recognize indicative, interrogative, imperative and subjunctive moods. But different human languages may distinguish different systems of mood. Arabic, for instance, has the indicative mood in statements, the interrogative in questions and the imperative in commands, but also the desiderative in relation to desires, wishes, prayers, implorations, and others. The desiderative mood in Arabic syntax is reminiscent of the optative mood in Greek, which as Lyons (1968, p. 308) says "(the Greek 'optative', which is distinct from the subjunctive', owes its name to the fact that one of its principal functions was conceived to be that of expressing wishes.)"

Modality is so intertwined with mood and tense that it is, as Palmer (1986, p. 2) says, "much more vague and leaves open a number of possible definitions, though something along the lines of Lyons' (1977: 425) 'opinion or attitude' of the speaker seems promising." In English, grammatical modality is principally conveyed by the modal auxiliaries: may might, must, can, could, will, would, shall, should and ought to. These auxiliaries are used in English syntax to signal a range of modalities including, inter alia, obligative, inferential, necessary and possible propositions. In Arabic, however, the system of modality hinges on the use of quasi-auxiliaries as well as particles like layta, inna, Sasaa, пиипиttawkiid 'the $\mathrm{n}$ of emphasis', law, qad, and others. These and related morphemes/words are linguistic means which not only express the opinions and attitudes of speakers towards a proposition, but also influence the behaviour of interlocutors. For instance, qad in qad najaht 'I have certainly passed' the speaker intends to make it absolutely beyond doubt that he passed. This contrasts with najaht 'I have passed' which falls short of definitely convincing the addressee of the credibility of the claim. ElHassan (1990, p. 153) says that, Arabic grammarians have not explicitly recognized 'modality' as a separate syntactico-semantic category. 
For lack of a better term, El-Hassan (1990) suggests 'al-mawqifiyya' -which can roughly be translated as 'attitude'- as a tentative mnemonic 'equivalent' of modality since the essence of modality as described by western linguists (e.g., Lyons, Palmer, Mitchell, and others) is concerned with the expression of speakers' opinions and attitudes. As in Mitchell and El-Hassan (1994, p. 7), speakers use the available modal means in their languages not only to indicate their own psychological and social stance towards a proposition, but also to influence the attitudes and behaviour of collocutors. Mood and modality, therefore, are interrelated and both of them encode illocutions and perlocutions in the daily functions of human languages. Mood handles verb inflections along with their respective illocutionary and perlocutionary force in speech and writing, while modality, for its part, reflects the interlocutors' opinions and attitudes. It indicates speakers' commitments with regard to what they utter and it involves such notions as possibility necessity, prediction, permission, intention, desire, wish, among other functions (cf. Palmer, 1986, 1979, 1974).

Non-factivity, which quite often finds expression in the subjunctive and desiderative-cum-optative moods "subsumes notions of will, intention, desire, prediction, likelihood, and even possibility and necessity as they relate to such notions" (Mitchell \& El-Hassan, 1994, p. 13). Hence, non-factivity will, along with mood and modality, merit some discussion here insofar as it pertains to unrealizable utterances. To give just one example of non-factivity at this juncture, consider (13).

13. It is likely that he won the million 'mina lmuhtamali Pannahu rabiћa lmaljoon.'

The proposition is non-factive in contrast with factive (14), which presupposes that the million was won.

14. It is surprising that he won the million 'mina lmudhiši Pannahu rabiћa lmalyoon.'

Although 13 and 14 seem to have fairly similar surface structure, yet there are some deep syntactic and semantic contrasts between them (cf. Kiparsky \& Kiparsky, 1971). It is important for the purpose of this article to point out that the contrasts between these different moods in English and Arabic are not invariably associated with verb inflexions; a variety of morphological, syntactic and phonological devices are involved. For instance, intonation can distinguish between the indicative and the interrogative in both languages.

As mentioned above, the concepts of mood and modality are very complex indeed; hence any detailed analysis of them is beyond the scope of this article. It is only with regard to their interlanguage translatability that they are of relevance to the present study. Furthermore, only two of the moods - the subjunctive and the desiderative (optative) - are of direct relevance because they are vehicles for unrealized/ unrealizable propositions. Now consider the following example.

15. The headmistress must be at school (now).

This sentence is ambiguous: it can be construed as an obligation or an inference. The modal auxiliary must is the source of this ambiguity. The speaker is either exercising his authority to make it necessary that the headmistress be at school, or is saying that, as Palmer $(1979$, p. 48) would put it, "the only possible conclusion" is that the headmistress is at school. Such a conclusion is based on circumstantial evidence and/or past experience. The Arabic translation of (15) must recognize and bring out this dual interpretation, viz.:

a. jadzibu Pan takuuna lmudiiratu fil madrasati (lPaan)

b. laa budda Panna lmudiirata fil madrasati (lPaan)

Both interpretations in English and in Arabic are modalized and stand in contrast with the indicative mood in (16).

16. The headmistress is at school (now) 'Palmudiiratu fil madrasati (lPaan). 
The indicative mood here expresses an assertion which is likely to be true, or not. Modality examples which convey non-realizability include English expressions with may, might, should, ought to and could along with the present perfect construction (have+ past participle) as in 17.

17. You might at least have told me 'kaana Pahraa bika Yala lPaqalli Pan tuxbiranii.'

This example not only presupposes non-realizability, but also implies rebuke and taking the addressee to task for negligence of a (moral) responsibility. A similar sense of negligence, and perhaps objection, is reflected in 18 .

18. He should/ ought to have apologized 'kaana janbağii Pan jaStaðira.'

Following are some more examples of the translatability of sentences involving the accomplishable, be it in the context of tense, conditionality, mood, modality, non-factivity, or others.

19. I wish I were a soldier '?atamannaa law kuntu dzundijjan' (past tense, non-past time) or Patamannaa law Pannani dzundijjun.'

This sentence can also be translated as in (a) using the wishful word layta.

a. laytanii kuntu dzundijjan.

20. Had you asked me, I would have helped you 'law (kunta) sa?altanii lakuntu saaSadtuka.

The apodosis here was not realized because the protasis was not realized. Arabic grammarians characterized the conditional particle law as 'harfu mtinaaSin limtinaa؟', that is, a particle whose apodosis is unaccomplished because the protasis is unaccomplished. According to Ibn Aqiil (p. 385), Siibawayh interpreted law as "A particle for the occurrence of an event that would have happened in consequence to that of another." This particle more often than not attracts a past tense verb with a nonpast time interpretation. When law is followed by a non-past tense, it too has a past time interpretation. Ibn Aqiil (p. 389), as in KuӨayyir Azza's verse:

21. law jasmaGuuna kama sami@tuka laama haaxarruuli Cazzatarukka Gan wasujuudaa.

In this line of verse, the poet praises his sweetheart, Azzah, saying that if they (the monks of Madyan) heard (lit. hear) her discourse as I have heard it, they would kneel and prostrate themselves before her. In the previously mentioned reference, Ibn Aqiil interprets law jasmaGuun 'if they hear' as law samiGuu with a past tense, non-past time. The desiderative unrealizability-cum-unreality of the poet's wish is quite obvious. Here are a couple of examples of Arabic verse where this conditional particle is employed.

22. law jastaTii9u litaqtiirihi tanaffasa min minxarin waahidi

This line of verse condemns a stingy person who would if he could breathe via one nostril only. This example depicts a present state of affairs which is well-nigh impossible to maintain for normal breathing. The next line of verse expresses a wish equally unrealizable.

23. law kaana juhdaa Pila linsaani qiimatuhu lakaana juhdaa laka ddunjaawa maa fiihaa 'if a gift were to be commensurate with the beneficiary's worth, yours would then have to be the world and what it contained.'

In Modern Standard Arabic, the particle law collocates with the past tense form of w-d-d 'wish/long to' as in 24 and 25.

24. wadadtu law tuğajjiru suluukaka 'would you change your behaviour/I wish you would change your behaviour.'

25. wadduu law jarudduunaka Pila lkufr 'they longed to turn you back to disbelief.'

The implication is that such longing is mere wishful thinking. The use of law is an exponent of the non-realizability of the event. Note that traditional grammarians of Arabic are quite dogmatic in their 
descriptive (or rather prescriptive) statements. One wonders if, for instance, Ibn Aqiil's claim mentioned above, that is, that a non-past tense rarely follows law, and when it does it conveys a past time sense, is tenable. Language is much more flexible and, although rule governed, it quite often defies strait-jacketing. Consider 26 (a \& b).

26.

a. law samiৎa lwaladu taћðiira waalidihi lamaa Padmana Sala ttadxiin 'Had the boy heeded his father's warning, he wouldn't have become addicted to smoking.'

b. law jasmaৎu lwaladu taћðiira waalidihi farubbamaa jaslamu mina 1Pidmaani Gala ttadxiin 'if the boy listens to his father's warning, maybe he will be saved from addiction to smoking.'

In 26 (a), the entire situation (apodosis and protasis) relates to past time: The boy did not pay heed to his father's warning, and consequently he did not spare himself addiction. In contrast, 26 (b) encodes a situation in future time: if the boy heeds, maybe he will not become an addict. The point to observe in 26 (b) is that law is followed by a non-past tense which, contrary to what Ibn Aqiil claims, does not signal past time. This counter claim is indeed supported by several Quranic verses which confirm the suggestion that law can be followed by non-past tense with a non-past time interpretation. For instance, verse 42 in Surat Al-Nisaa' lends support to this suggestion.

$$
\text { "يومئذٍ يودُ الذين كفرواو عصوا الرسولَ لو تُسوّى بهم الارضنُ و لا بكتمون اللَّحديثا" }
$$

'On that day (i.e., The Day of Judgement) those who disbelieved and disobeyed the Messenger (of Allah) will wish to be levelled to the ground, and are unable to conceal (a piece of) discourse from Allah.'

Evidently, their wish on that day will be unrealizable. The following verses also present law with a non-past verb conveying future time reference: 96/Albaqara, 11/Alma'aarij. These and several Quranic verses are introduced by the matrix verb w-d-d 'to wish/long to' itself in a past or non-past tense form expressing an unrealized and unattainable wish echoed and reinforced by the equally unrealizable/unattainable situation in the embedded law phrase. Thus, the English language translator has to fully comprehend the sense of such Arabic phrases and sentences in order to render correctly the non-realizability of the conditions involved.

Related to the above-mentioned linguistic situations in Arabic are phrases and sentences with the particle lawlaa. For example:

27. lawla nniilu lakaanat miSru qafran 'Had it not been for the Nile, Egypt would have been a wasteland.'

Egypt is not a wasteland because of the existence of the Nile. In general, the essence of phrases with lawlaa can be summed up as follows:

$\mathrm{X}$ is there because $\mathrm{Y}$ is not, or $\mathrm{X}$ is not there because $\mathrm{Y}$ is there.

Arabic grammarians described lawlaa as harfu mtinaal liwujuud 'a particle for the non-occurrence of something due to the existence of something else.' Its translation into English as shown above is 'had it not been for', or 'if it hadn't been for', both of which match the non-realizability of the apodosis in the Arabic sentence in 27 above. Obviously, a negative conditionality is initiated by the protasis governed by lawlaa, and similarly by the corresponding English translation. These conditional particles (i.e., law and lawlaa) are very common in Modern Standard and Spoken Arabic, allowing for the fact that in spoken day-to-day discourse, lawlaa is pronounced loolaa in some Arabic dialects (e.g., Jordan and Palestine). A couple of vernacular examples will suffice:

28. law baddi batdzawwaz kamaan wahadih 'if it were my wish, I would marry another(wife).' 
Both the protasis and the apodosis are interdependent and neither is realizable. The quasi-verb badd and its pronominal conjugations (e.g., badd-i, badd-uh, bad-ha, bad-hum) tend to collocate fairly consistently with the particle law.

29. loola ttaTYiim bimuutu lPaTfaal 'if it were not for vaccination, children would die.'

30. loola lYaaSifih kunna zurnaaku 'Had it not been for the storm, we would have visited you.'

The temporal difference of the non-realizability of 29 and 30 is clear: The former talks about what may be considered a medical fact (children's death) obviated by a medical act (vaccination); the latter describes a past time condition (storm) which prevented the occurrence of an event (visit). The grammatical device which triggers such interdependent elements of structure is conditionality, and both English and Arabic use their respective syntactic means to achieve this end. The intertranslatability poses no hindrance beyond the adequate knowledge of the translator. If the apodosis is negated in conjunction with lawlaalloola, the double negative renders the apodosis real and fulfilled, as in 31 which presupposes Aleppo was destroyed and 32 which presupposes that we came.

31. lawla tharb maa dummirat halab 'if it hadn't been for the war, Aleppo wouldn't have been destroyed.'

32. loola Sjuunak maa dziina 'if it hadn't been for your sake (lit. of your eyes) we wouldn't have come.'

This function of lawlaa must be distinguished from that of a homophonous correlative which Arabic grammarians categorize as a particle of spurring and/or censure. When it governs a non-past tense, it urges the subject of the verb in the strongest terms to do what is required of him. This aspect of lawlaa will not be pursued here. What concerns us in this article is its role in the context of a past tense where the subject of the verb (i.e., the interlocutor) is censured and held to account for failing to act. The perlocutionary effect is to evoke in the hearers a sense of guilt and regret for negligence of their duty. Consider the following examples from the Holy Quran:Surat Al-An'am, verse 43.

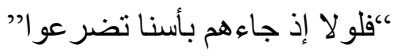

'If only when Our affliction approached them, they supplicated (God's mercy). Or, 'why, when our affliction came unto them, did they not call Allah in humility?'

But alas! They did not, and consequently suffered His severe punishment. Implied in this verse is a feeling of admonition and rebuke. Surat Az-Zukhruf verse 53.

$$
\text { “فلو لا أُلقي عليه أسورةٌ من ذهب” }
$$

'If only bracelets of gold were sent down upon him (from heaven).' Or, 'why aren't bracelets of gold sent down upon him?'

This verse is an expression of Pharaoh's argument to refute the mission of Moses (peace be upon him); gold bracelets from Allah would have been proof of Moses' mission, suggests the Pharaoh who held his people in contempt by this suggestion.

\section{Conclusion}

This article brings into focus the meaning of hypothetical, unrealized and/or unrealizable propositions encoded by the use of auxiliary verbs or semi-verbs and by a variety of particles whose function is to generate and support these propositions and notions in English and Arabic. The article, moreover, asserts the interlanguage translatability of such propositions and notions. In principle, but by no means exclusively, Arabic is treated as a source language and English as a target language for the purpose of translation. But in many places, this order of the two languages is reversed. The article 
concludes that the relevant propositions, along with the sentences used as vehicles for affecting them, lend themselves with ease to the process of interlanguage translatability. Consider 33 and 34.

33. I wish I had a true friend (now) 'lajta Sindii Sadiiqan muxliSan (Pil?aan).'

Note that *I wish I have is ungrammatical.

34. If you tried again, you might succeed 'law tuhaawilu $\theta$ aanijatan farubbamaa tandzah.'

(cf. Pintuhaawil which renders the proposition real and likely to happen. On the other hand, Riðaa haawalat does not only make it real, but probably makes it more or less imminent.)

As these two examples indicate, the unreal/non-realized/non-realizable locutions dealt with in the main text of the article are contrasted with real/realizable counterparts to drive home the argument.

\section{References}

Al-Dagar, A. (1982). Mu'jamu Al-Nahw ( $2^{\text {nd }}$ Ed.), Beirut: United Company of Distribution.

Alhawary, M. (2016). Arabic grammar in context. Oxon: Routledge.

Al-Mahjoob, N. (2016). Modals in English and Arabic legal texts. Journal of Al-Frahedis Arts, 2(27), $1-27$.

Al-Qudah, M. \& Yasin, A. (2016). The Perception of English modals among Arab language learners. International Journal of Applied Linguistics \& English Literature, 5(3), 282-289.

Anghelescu, N. (1999). Modalities and grammaticalization in Arabic. In Y. Suleiman (Ed.), Arabic grammar and linguistics (pp. 107-142). Oxon: Routledge.

Burton-Roberts, N. (2016). Analysing sentences: An introduction to English syntax (4 ${ }^{\text {th }}$ Ed.), Oxon: Routledge.

Eades, D. (2011). Translating English modal expressions: An Arab translator trainee's perspective. Babel, 57(3), 283-304.

El-Hassan, S. (1990). Modality in English and Standard Arabic: Paraphrase and equivalence. Journal of King Saud University, 2(2), 149-166.

Fenn, P. \& Schwab, G. (2018). Introducing English syntax. Oxon: Routledge.

Gadallah, H. (2017). Translating tenses in Arabic-English and English-Arabic contexts. Newcastle Upon Tyne: Cambridge Scholars Publishing.

Inb Aqiil, B. (undated). Sharh Ibn Aqiil of Ibn Malik’s Thousand-Verse Poem.

Kiparsky, P. \& Kiparsky, C. (1971). Fact. In D. D. Steinberg \& L. Jakobovits (Eds), Semantics.

Larreya, P. (2009). Towards a typology of modality in language. In R. Salkie, P. Busuttil \& J. Auwera (Eds.), Modality in English: Theory and Description (pp. 9-30). Berlin: Mounton de Gruyter.

Lyons, J. (1977). Semantics. Cambridge: Cambridge University Press.

Lyons, J. (1968). Introduction to theoretical linguistics. Cambridge: Cambridge University Press.

Mahdi, S. \& Husain, A. (2012). Translating modality of English legal texts into Arabic. The Journal of the Faculty of Basic Education, 76, 67-82.

Mitchell, T. \& El-Hassan, S. (1994). Modality, mood and aspect in Spoken Arabic. London: Kegan Paul International. 
Moindjie, M. (2015). The function of modality in translation. International Journal of Comparative Literature \& Translation Studies, 3(2), 11-24.

Ouali, H. (2018). The syntax of tense in Arabic. In E. Benmamoun \& R. Bassiouney (Eds.), The Routledge Handbook of Arabic Linguistics (pp. 89-103). Oxon: Routledge.

Palmer, F. (1986, 2001). Mood and modality. Cambridge: Cambridge University Press.

Palmer, F. (1979). Modality and the English modals. London: Longman.

Palmer, F. (1974). The English verb. London: Longman.

Portner, P. (2009). Modality. Oxford: Oxford University Press.

Ryding, K. (2005). A reference grammar of Modern Standard Arabic. Cambridge: Cambridge University Press.

Sterling, R. (1904, 2018). A grammar of the Arabic language. Oxon: Routledge.

\section{AUTHOR BIODATA}

Bashar Al-Rashdan is Associate Professor of Linguistics in the Department of English at Mu'tah University. $\mathrm{He}$ specialises in linguistics and phonological studies. He published his research in journals such as Jordan Journal of Modern Languages and Literatures. His mail ID is bashar-el-rashdan@ hotmail.com

Imran Alrashdan is Assistant Professor of Linguistics in the Department of English Language and Literature at the University of Jordan. He specialises in syntax, with a focus on negation in Jordanian Arabic. He published his research in journals such as Sage Open and Ampersand. His mail ID is i.alrashdan@ju.edu.jo

Mohd Nour Al Salem is Assistant Professor of Translation in the Department of English Language and Literature at the University of Jordan. He specialises in literary translation. He published his research in journals such as Lingue e Linguaggio and Ampersand. His mail ID is mo.alsalem@ju.edu.jo

Sharif Alghazo is Associate Professor of Applied Linguistics in the Department of English Language and Literature at the University of Jordan. He specialises in English pronunciation. He published his research in journals such as Interchange, Lingue e Linguaggio, Open Linguistics and Ampersand. His mail ID is s.alghazo@ju.edu.jo 